\begin{tabular}{cc|c}
\hline Tar. Bil. Der. & Tarm Bilimleri Dergisi & Journal of Agricultural Sciences \\
& $\begin{array}{c}\text { Dergi web sayfası: } \\
\text { www.agri.ankara.edu.tr/dergi }\end{array}$ & Journal homepage: \\
& www.agri.ankara.edu.tr/journal
\end{tabular}

\title{
Effects of Tobacco Etch Virus (TEV) on the Yield and Quality of Karaisali Pepper Populations
}

\author{
Pelin KELEŞ ÖZTÜRK ${ }^{a}$, Duygu ARGÜN ${ }^{\mathrm{b}}$, Saadettin BALOĞLU ${ }^{\mathrm{c}}$, Davut KELEŞ ${ }^{\mathrm{b}}$ \\ ${ }^{a}$ Biological Control Research Institute, Adana, TURKEY \\ ${ }^{b}$ Alata Horticultural Research Institute, Mersin, TURKEY \\ ${ }^{c}$ University of Cukurova Faculty of Agriculture Department of Plant Protection, Adana, TURKEY
}

\section{ARTICLE INFO}

Research Article DOI: 10.15832/ankutbd.418284

Corresponding Author: Pelin KELEŞ ÖZTÜRK, E-mail: pkelesoz@hotmail.com, Tel: +90 (322) 3441784

Received: 24 April 2018, Received in Revised Form: 15 October 2018, Accepted: 26 November 2018

\begin{abstract}
The Eastern Mediterranean Region has a significant potential for capia pepper production in Turkey. In the region, a population named as 'Karaisali pepper' with special characteristics, is grown. The population is well-adapted to the region and grown for processing. Karaisali pepper is usually preferred for red pepper production due to its high dry matter content. Survey studies conducted on Karaisali pepper in 2014 and 2015 demonstrated that the Tobacco etch virus (TEV) was the most common and destructive virus affecting Karaisali pepper. In the present study, three pure lines derived from Karaisali pepper were used to assess their susceptibilities against TEV. The experiment included mechanically inoculated infected plants and healthy pepper plants in the control group. The pepper plants were inoculated with the TEV using mechanical inoculation method during the four-leaf stage. The plants were observed periodically after mechanical inoculation. Each repetition was analyzed based on the total yield, pepper paste yield, fruit size, soluble solid content, fruit color and market value. The result indicated that, in average, TEV reduced Karaisali pepper yield by $77.5 \%$ and pepper paste yield by $33.6 \%$. Furthermore, the average fruit length (37\%), fruit diameter $(21.4 \%)$, fruit wall thickness $(14.2 \%)$, fruit volume $(60.2 \%)$ and first quality fruit ratio were also decreased. The results confirm the threats of TEV in pepper production.
\end{abstract}

Keywords: Tobacco etch virus; Pepper; Yield; Quality

(C) Ankara Üniversitesi Ziraat Fakültesi

\section{Introduction}

Pepper is cultivated on 805.166 acres in Turkey and total production of pepper were 2.608.172 tons; 1.107.713 tons of it were capia pepper production (TSI 2017). The Karaisali pepper is a local population, widely cultivated as a main and second crop in Adana province, with a high dry matter content, and it is used for pepper paste and grilled pepper production in the industry. Different viruses significantly affect the growth and development of different plant species. For that reason, Friess \& Maillet (1997) for chickweed, Johnson \& Main (1983) for tobacco, Taiwo \& Akinjogunla (2006) for cowpea, Nascimento et al (2006) for peanut and Al-Saleh et al (2007) for peanut carried out comprehensive studies. Different viruses in pepper 
cause considerable amount and quality losses. Pazarlar et al (2013) studied changes in some growth (plant leaf number and area, plant biomass, plant height, root length, and plant stem diameter) and physiological (photosynthetic pigments, relative water content (RWC) and proline content) parameters of pepper (Capsicum annuиm L.) varieties as they were affected by Tobacco mosaic virus (TMV) infection. Infected plants showed various degrees of stunting, necrosis on stems, leaves and fruits, mosaic symptoms on leaves, deformations, defoliation of leaves, and reduction in fruit size. TEV is among the major viruses that infect pepper plants cultivated in open fields and cause infections (Buzkan et al 2012; Fidan \& Keleş Öztürk 2013). TEV is transmitted in a non-persistent manner by aphids and its most important vector is Myzus persicae. TEV is observed as single infection on pepper or as mixed infections with Potato Y virus (PVY). Its incidence could be as high as $100 \%$ at harvest time (Padgett et al 1987). Yield reduction due to TEV can reach up to $70 \%$ (Koenning \& McClure 1981). Murphy \& Morawo (2017) evaluated TEV strains HAT, Mex21, and N for their pathogenicity and effects on growth of 'Calwonder' pepper. Effects on plant growth parameters closely reflected disease symptoms induced by each TEV strain. HAT-infected Calwonder plants did not differ from the healthy control for plant height, internode lengths, and above ground fresh weight of shoots. In the present study, a greenhouse experiment was constructed to investigate response of pepper plants against the TEV agent, which has been identified in Karaisali pepper populations and noticed that it has an impact on the crop. In this experiment, three prominent pure Karaisali pepper lines were inoculated with TEV using mechanical inoculation method and the yield and quality losses in Karaisali pepper population due to this virus were determined.

\section{Material and Methods}

K7, K25, K34 pure pepper line seeds obtained from the Alata Horticultural Research Institute in Mersin were planted. These specific lines were selected because of their overall promising horticultural attributes. The plants were grown in a greenhouse having full control and drip irrigation systems, and some chemical fertilizers and pesticides were applied when necessary. In pomological analyzes scales, rulers, refractometer, calipers, 2 and 5 liter beakers were used for measurements.

\subsection{Cultivation of Karaisali pepper population lines}

The line reaction experiment was carried out in greenhouses in the Alata Horticultural Research Institute in 2015 and 2016 years. The experiment was conducted using a randomized blocks design, with a control for each line, five repetitions and 25 plants were grown in each repetition. The experiment included virus-infected pepper plants and healthy pepper plants in the control group. The seeds were planted in viols located in a climate room during the first week of March due to climate requirements and the developed seedlings were transferred into the fully-controlled greenhouses in the middle of April when they were at the stage of 3-4 leaf and routine applications were applied.

\subsection{Inoculation of virus isolate by mechanical inoculation method}

During the surveys carried out in 2014-2015, TEV, which was the most destructive virus species in Karaisali pepper, local population cultivated widely in Karaisali district of Adana province, was isolated from a single virus infected pepper plant and inoculated on test pepper plants for reproducing the virus. Leaf samples obtained from pepper plants, which were determined to be infected by TEV using double antibody sandwich enzymelinked immunosorbent assay (DAS-ELISA) test, were crushed in a porcelain container with 0,02 $\mathrm{M}$ potassium phosphate buffer ( $\mathrm{pH} 7.0) \quad(0.02$ $\mathrm{M} \mathrm{KH_{2 }} \mathrm{PO}_{4}, 0.02 \mathrm{M} \mathrm{Na}_{2} \mathrm{HPO}_{4}$ ) containing $0.1 \%$ 2-mercaptoethanol at the rate of 1:5 (w/v). The obtained inoculum was filtered through 2 layers of cheesecloth. The leaves of the pepper lines were dusted with carborumdum powder then the inoculum was rubbed on to the leaves using a sponge (Çelik et al 2010). After inoculation, the plant leaves were washed with tap water to remove carborundum 
powder and plant residues. The virus symptoms were observed 10-15 days after inoculation and confirmed by the DAS-ELISA (Clark \& Adams 1977).

\subsection{Fruit yield}

At this stage, pepper fruits harvested from the control and virus-infected plots were classified based on the fruit size and the total fruit weight in each plot was determined. Pepper paste was produced from these Karaisali pepper lines, and the paste yield was determined.

\subsection{Fruit quality}

When the pepper fruits in plots reached the harvest maturity, the following fruit quality properties were examined (IPGRI 1995). For fruit quality examination, pepper fruits collected at the second harvest were used. For every repetition in healthy and infected plots, 25 pepper fruits representing each line were selected. A total of 375 healthy and 375 infected pepper fruits were examined for 3 lines, 125 pepper fruits each line. The effect of TEV on average fruit diameter $(\mathrm{cm})$, average fruit length $(\mathrm{cm})$, average fruit volume $(\mathrm{mL})$, fruit wall thickness $(\mathrm{mm})$, fruit color, fruit total dry matter production (\%), fresh and dry weight of all green parts $(\mathrm{kg})$ and market value $\left(1^{\text {st }}\right.$ quality: $16-18 \mathrm{~cm}$, smooth, shiny, with the color specific to the species; $2^{\text {nd }}$ quality: small fruits, deformed, cracked, with distorted color) of the fruits were determined. The results of the experiment were analyzed with JMP statistics software LSD test and at 5\% significance level. In the experiment related to responses of pepper lines to TEV, the yield and quality losses caused by the virus in peppers were determined by the following formula:

The $\%$ effect of the reaction test $=($ Application $/$ control $) \times 100$

\section{Results and Discussion}

\subsection{Analysis of fruit and paste yields}

The yield was recorded during five harvesting periods. In 2016, however, three harvesting periods were made due to low fruit yield in the infected plots and five harvests were made in healthy plots. The average yield values, loss ratios and analysis results for the healthy and infected line plots are presented in Table 1. The yield loss ratios caused by TEV infection were determined for K7 (59.9\% and 95.1\%), K25 (48.2\% and 86.3\%) and K34 (13.4\% and $82.5 \%$ ) lines in 2015 and 2016, respectively. Nutter et al (1989) also conducted field experiments in northeast Georgia to quantify the effect of TEV epidemics on yield of pepper. They found that early season infection reduced yield 74\% in 1986 and $73 \%$ in 1987 . The disease severity varied between 2015 and 2016 in the line reaction experiments. In both years, the experiment was conducted in midApril. There were differences in yield between two consecutive years, probably due to impact of climatic changes that occurred in the immediate aftermath of inoculation, probably affecting the propagation and spread of the virus in the plant. In the healthy and infected plots in both years, the decrease in the yield was parallel and correlated. In the present study, K34 line was the least affected line by TEV infection based on average yield. Ramkat et al (2006) was conducted a study in a greenhouse to determine the effect of mechanical inoculation of tomato spotted wilt tospovirus (TSWV) on the severity of the disease on tomato varieties 'Cal J', 'Marglobe', 'Money maker', 'Roma' and 'Riogrande' and its impact on yield. Mechanical inoculation reduced total yield of 'Cal J', 'Riogrande', 'Money maker', 'Marglobe' and 'Roma' by 60, 55.3, 45.1, 40.3 and $27 \%$, respectively. The effects of TSWV on yield and quality of tomato fruits were also studied in Samsun Province of Turkey in 2004. It was found that TSWV caused $42.1 \%$ and $95.5 \%$ reduction in yield and marketable value of tomato, respectively, (Sevik \& Arl1-Sokmen 2012). Furthermore, pepper paste was made using each repetition of healthy and infected plots of three pepper lines. Statistical analysis regarding the paste weight is presented in Table 1. Loss ratios demonstrated that K34 line exhibited the highest loss with $41.2 \%$, followed by K25 line with $25.7 \%$ and K7 line with $19.1 \%$ loss in 2015. In 2016, the line with the highest loss was K25 with $39.6 \%$, followed by K7 line with $36.7 \%$. The K34 line was the least reactive line with a $26 \%$ 
loss. Pepper paste was produced from pepper fruits and the dry matter content was measured with a refractometer. It was determined that the TEV did not decrease the dry matter content in the pepper paste (Table 2).

\subsection{Fruit quality}

\subsubsection{Dry matter production in fruit}

Pepper fruits were crushed and total dry matter content of fruit was examined with a digital refractometer. Examination of the water-soluble dry matter (WSDM) content of pepper fruits in the control and infected plant lines demonstrated that the difference between the applications was not statistically significant at 5\% level (Table 2). When infected pepper lines were compared to healthy plots in 2015, it was found that WSDM value was 0.1 brix- 0.6 brix high, while in 2016 , there was a 0.4-2.6 brix decrease in the WSDM value in all infected plant lines.

\subsubsection{Fruit weight}

Average fruit weight and percentage loss ratios for the lines were determined. Fruit weight loss was the highest in K34 line (48.5\%) in 2015, followed by K7 (46.1\%) and K25 (45.7\%) lines. In 2016, the K7 line exhibited the highest loss with $56.4 \%$, followed by $\mathrm{K} 25$ with $53.1 \%$ loss and K34 with $42 \%$ loss (Table 3). Padgett et al (1990) also reported that, TEV affected pepper yield by reducing the average weight of the fruit and the number of fruit. Ramkat et al (2006) observed that, TSWV inoculation on tomatoes caused reduction of varying magnitudes in total fruit weight when compared to their health controls.

\subsubsection{Fruit diameter}

Table 3 demonstrates that the highest loss in fruit diameter among the lines in 2015 was observed in K34 line with $22.2 \%$, followed by K7 line with 20\% loss and K25 line with $12.1 \%$ loss, the highest loss in fruit diameter in 2016 was observed in K34 line with $20.5 \%$ loss, followed by K25 with $17.9 \%$ and K7 with $17.2 \%$ (Table 3).

\subsubsection{Fruit length}

Based on the average fruit length, the difference between applications in 2015 and 2016 was significant at 5\% for all lines. While K25 line exhibited the highest loss in 2015 with $41.9 \%$, K7 exhibited $35.1 \%$ and $\mathrm{K} 34$ exhibited $30.1 \%$ loss. In 2016, the K25 line exhibited the highest loss with $32.1 \%$, followed by K7 with $24.8 \%$ and K34 with $23.9 \%$ loss (Table 4). Fruit length of Karaisali pepper line is an important property in determining the market value. The minimum fruit length loss was recorded with K34 line in both experiment years.

\subsubsection{Fruit volume}

It was found that the difference in fruit volume between healthy control and infected K7, K25 and K34 line plants was significant at 5\% level for 2015 and 2016 (Table 4). In the 2015 reaction experiment, the highest loss in fruit volume among the applications was observed in K25 line with 49.7\%, followed by K34 with $49 \%$ and K7 with $45.6 \%$ loss. In 2016, the least fruit volume loss was observed in K34 line with 53.3\% among the K7, K25 and K34 lines. Fruit volume is important since it demonstrates that the fruit is fully grown in shape and size. When the line reaches its unique fruit volume, the dry matter/water ratio would be good, and the food quality increases. Because, this affects the balance of the secondary compounds in the fruit as well. This ensures a good taste. Furthermore, the volume and length of the fruit is important, facilitating the use of these types of peppers in industrial pepper paste and grilled pepper production.

\subsubsection{Fruit wall thickness}

In both years, the difference between applications in K7, K25 and K34 lines was not significant at 5\% significance level (Table 5). However, it was determined that there were losses in fruit wall thickness of all lines at varying ratios. The highest loss was found in K7 line with $16.6 \%$, followed by K25 with $11.8 \%$ and K34 with $10.1 \%$ in 2015 . In 2016, the highest loss was found in K34 with 13.2\%, followed by K7 with $11.8 \%$ and K25 9\%. 


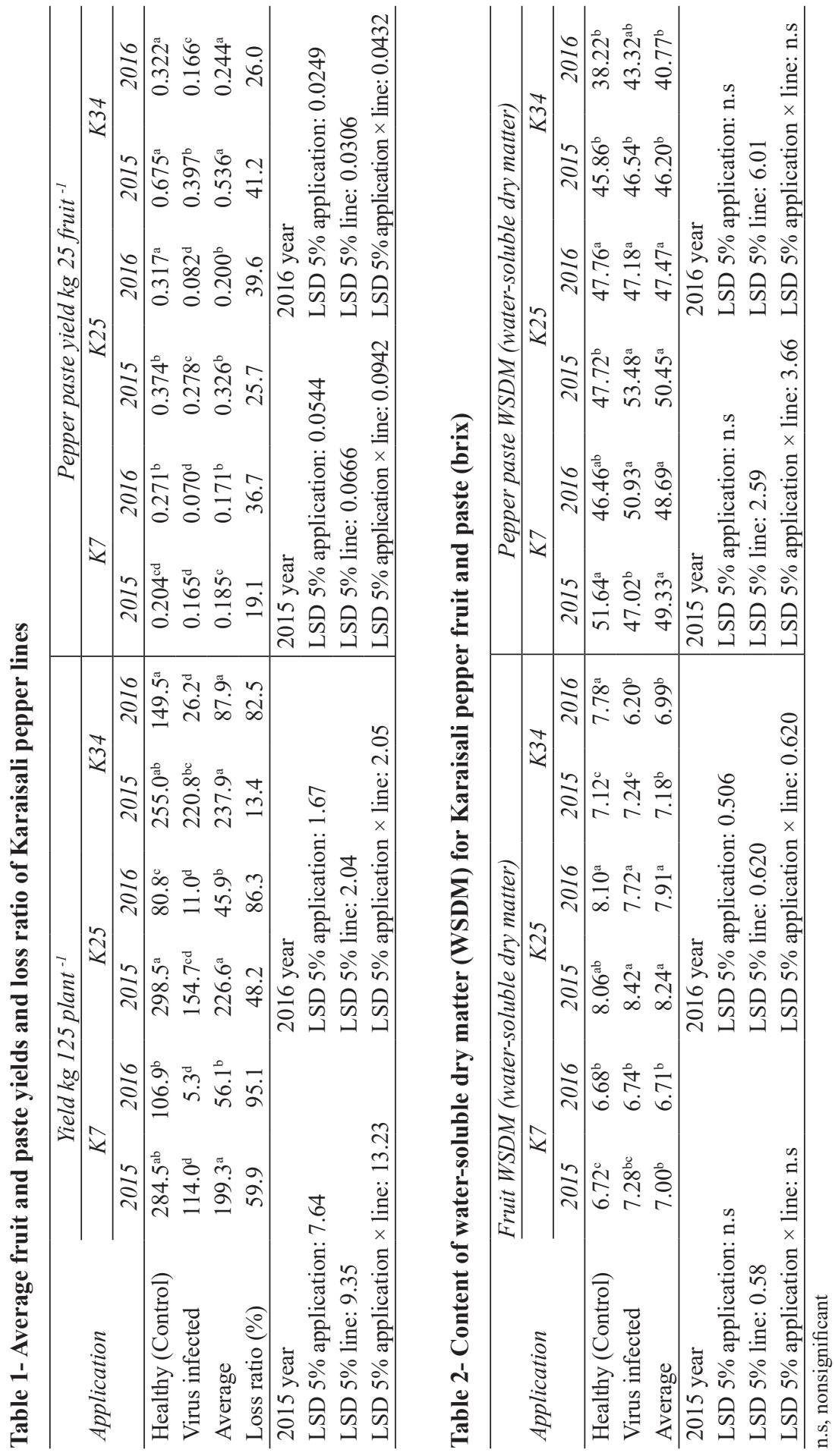

Tarım Bilimleri Dergisi - Journal of Agricultural Sciences 25 (2019) 247-257 

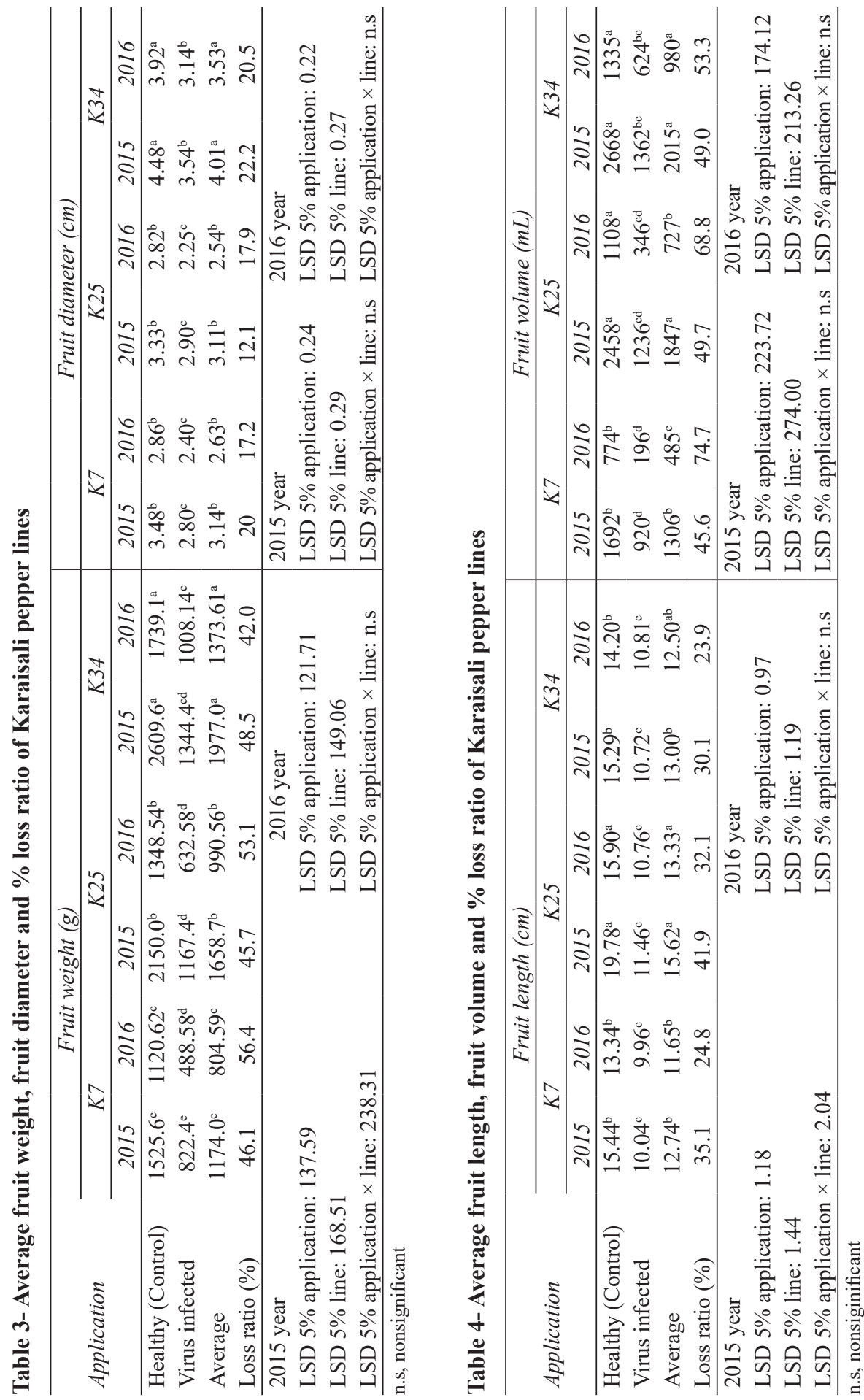


\subsubsection{Fruit color}

Fruit color was examined based on hue value (fruit color tone), a value (red-green) and L value (light-dark color) and statistical analyzes were conducted (Tables 5 and 6). Examination of the fruit color hue value demonstrated that there was no significant difference between healthy and infected plots in K7, K25 and K34 lines for 2015 at 5\% significance level. However, in 2016, a significant difference was found between the healthy and infected plots at 5\% significance level in $\mathrm{K} 7$ and $\mathrm{K} 34$ lines, however the difference was not significant in K25 line, similar to 2015 findings. The disease affected the $\mathrm{K} 7$ and $\mathrm{K} 34$ lines to acquire their true color. Based on 2015 data, the difference between the plots in all lines was not statistically significant based on fruit color a value (red-green) at 5\% significance level. The difference between the values for K7 and K34 lines was statistically significant in 2016 (Table 6). The difference between healthy and infected plots of all lines based on the fruit color $\mathrm{L}$ value (light-dark color) was not significant at 5\% significance level (Table 6).

\subsubsection{Fresh and dry weight of green parts}

Initially, the fresh weight of the green parts of the pepper plants removed after the final harvest was determined, and statistical analysis was conducted (Table 7). It was determined that for 2015, the maximum loss in fresh weight was recorded in K25 line (51.6\%), followed by K7 (48.4\%) and K34 (37.5\%) lines for 2015. Based on green parts fresh weight, highest loss was recorded in K34 line $(46.5 \%)$ in 2016 , followed by K7 line (46.3\%) (Table 7). The lowest loss was obtained by K25 line $(25.1 \%)$. Low green parts weight reflects lower photosynthesis, which in turn reduces the production of assimilative materials, reducing the yield and quality. In a study conducted by Murphy \& Bowen (2006), the correlation between root length and fresh weight was investigated on the isolates obtained from bell pepper plants mixed infected with CMV and PepMoV for each virus. For this purpose, they conducted three applications (only CMV, only PepMoV, and CMV+PepMov) and inoculated the viruses they isolated to pepper cultivars and used the
ELISA method for the diagnosis of viruses. In each experiment, they measured root length development and surface fresh weight. They found that these values were significantly lower for $\mathrm{CMV}+\mathrm{PepMoV}$ mixed infection when compared to species infected with a single virus. On the other hand, Murphy \& Morawo (2017) reported that above ground fresh weight of TEV-strain Mex21 infected pepper plants was significantly less than for the healthy control. Al-Saleh et al (2007) was evaluated selected peanut cultivars for reaction to TSWV in field plots in 2001, 2002, and 2003. They reported that across all three times of inoculation, significant reductions in fresh weight were observed in all cultivars except Okrun when inoculated at 5 days post-planting. Dry Weight of Green Parts: The green parts fresh weight was obtained for all lines and they were placed in brown paper bags and dried up to $10 \%$ humidity in an incubator at $55-60{ }^{\circ} \mathrm{C}$ and dry weigh data were obtained, and statistical analysis was conducted (Table 7). In 2015, the highest loss was recorded in K34 line (46.4\%), followed by K7 (45.9\%) and K25 (42\%). The highest loss in 2016 was recorded in K7 line (51.5\%), followed by K34 (43.7\%).

\subsubsection{Market value}

Market value of the fruits was determined as follows: $1^{\text {st }}$ quality: $16-18 \mathrm{~cm}$, smooth, shiny, with the color specific to the species; $2^{\text {nd }}$ quality: small fruits, deformed, cracked, with distorted color. The first and second quality counts and ratios for healthy plots for both years are presented in Table 8, and for infected lines; the same values are presented in Table 9. In general, when 2015 and 2016 figures are examined respectively, it was determined that the highest ratio of first quality pepper in healthy plots was observed in K25 (96.8\%, 69.6\%) line, while the same ratio decreased to $19.2 \%$ and $16 \%$ in the infected plots. Ramkat et al (2006) was found that TSWV caused a severe decrease in the marketable yield of the tomato fruits that was significant across the varieties. A $90 \%$ reduction in marketable yield was observed in variety ' $\mathrm{Cal} \mathrm{J}$ ' followed by 'Marglobe', 'Riogrande' and 'Money maker', with 62,41 and $40 \%$. 

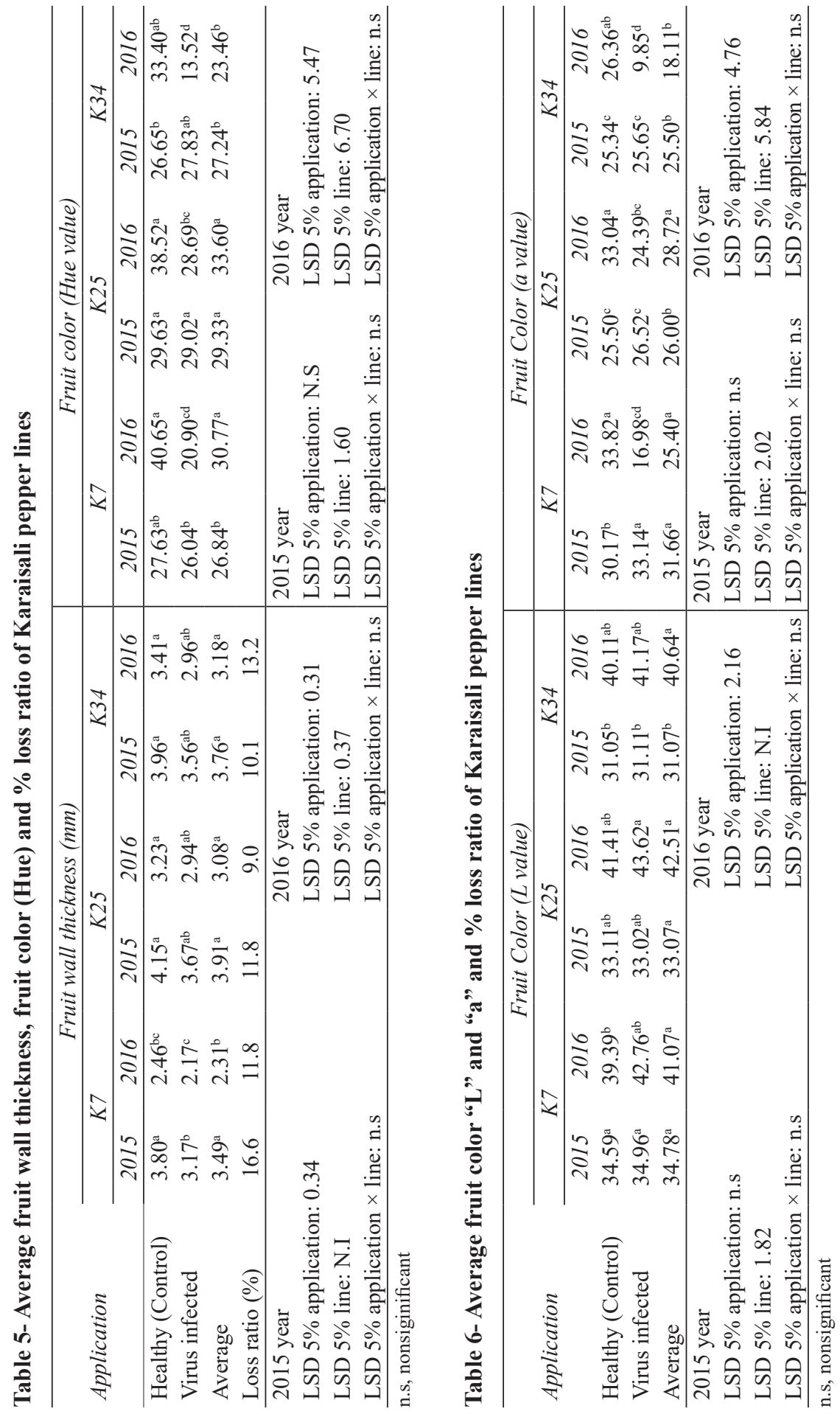


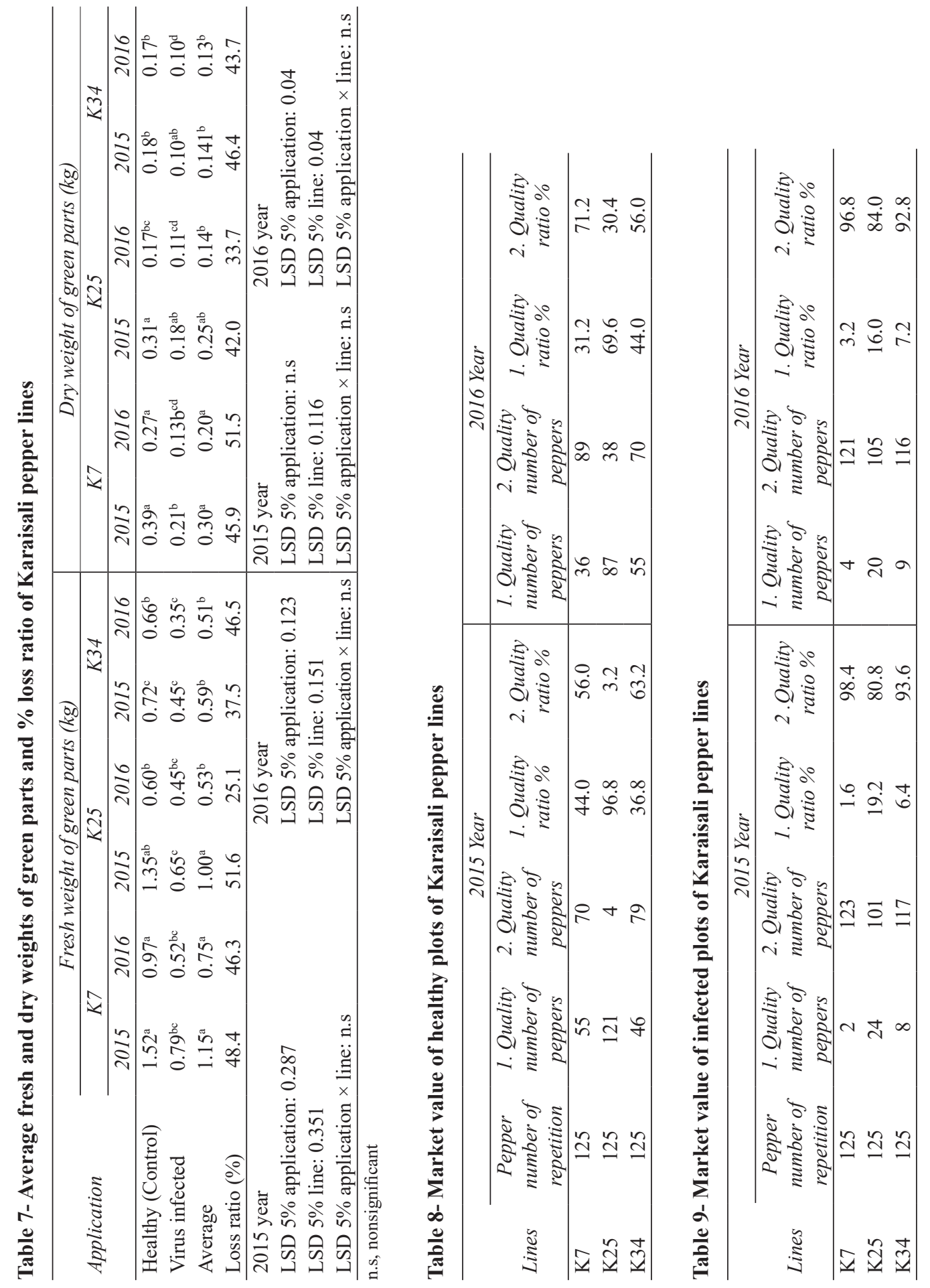




\section{Conclusions}

The present study involving yield and quality analyses demonstrated that the K34 line among the 3 good pepper lines obtained from the selective breeding of Karaisalı pepper populations by Alata Horticultural Research Institute Directorate was the less affected line by TEV when compared to other lines scrutinized in the study. The breeding institution applied to Seed Registration and Certification Center for the registration of the K34 line, which demonstrated high yield and quality properties and the lowest impact by the TEV agent and the seed was finally registered as the "Hayriye" variety. This study has shown the magnitude of yield and quality losses due to varying rates of TEV infection in Karaisali pepper lines grown under controlled conditions. To mitigate the damage caused by TEV, the cultural measures such as ways to prevent virus infection can be undertaken. However, the use of resistant cultivars could be the ultimate solution. Since significant differences among the pepper lines for the loss and damage were also recovered, our results suggest that new pepper cultivars exhibiting overall Karaisalı pepper attributes and minimizing the TEV damage could be developed.

\section{Acknowledgements}

The present study was conducted in the context of the TUBITAK project no: 1001-213 O 101, and a part of the study was presented as a proceeding at the $7^{\text {th }}$ International Plant Protection Congress, organized in Konya, Turkey on September 5-8, 2016. We would like to thank the Scientific and Technological Research Council of Turkey (TUBITAK) for all their support.

\section{References}

Al-Saleh M A, Melouk H A \& Mulder P (2007). Reaction of peanut cultivars to tomato spotted wilt virus (TSWV) under field conditions and their response to mechanical inoculation by TSWV under greenhouse conditions. Peanut Science 34: 44-52

Buzkan N, Arpacı B B, Simon V, Fakhfakh H \& Moury B (2012). High prevalence of poleroviruses in field- grown pepper in Turkey and Tunisia. Springer Verlag Vien, 10.1007/00705-012-1553-y

Clark M F \& Adams A N (1997). Characteristics of the microplate method of enzyme linked immunosorbent assay for detection of plant viruses. Journal of General Virology 34: 475-483

Çelik N, Özalp R \& Çelik İ (2010). Bazı biber hat ve çeşitlerinin tobacco mosaic tobamovirus (TMV)'e dayanıklılığının mekanik inokulasyon ve elisa testleri ile belirlenmesi. Batı Akdeniz Tarımsal Araştırma Enstitüsü Derim Dergisi 27(2): 1-9

Fidan H \& Keleş Öztürk P (2013). Salçalık biber üretim alanlarında potansiyel virüs hastalıkları. Agromedya Dergisi 6: 54-55

Friess N \& Maillet J (1997). Influence of cucumber mosaic virus infection on the competitive ability and reproduction of chickweed (Stellaria media). New Phytologist 135: 667-674

IPGRI (1995). International Plant Genetic Resources Institute, Descriptors for Capsicum (Capsicum spp.), pp. 33-38

Johnson C S \& Main C E (1983). Yield/Quality trade-offs of tobacco mosaic virus-resistant tobacco cultivars in relation to disease management. Plant Disease 67(8): 886-890

Koenning S R \& McClure M A (1981). Interaction of two Potyviruses and Meloidogyne incognita in Chili pepper, Phytopathology 71: 404-408

Murphy J F \& Bowen K L (2006). Synergistic disease in pepper caused by the mixed infection of cucumber mosaic virus and pepper mottle virus. Phytopathology 96(3): 240-247

Murphy J F \& Morawo T (2017). Comparative evaluation of disease induced by three strains of tobacco etch virus in Capsicum annuum L. Plant Disease 101: 217-223

Nascimento L C do, Pensuk V, Costa N P da, Filho F M de A, Pio-Ribeiro G, Deom C M \& Sherwood J (2006). Evaluation of peanut genotypes for resistance to Tomato spotted wilt virus by mechanical and thrips inoculation. Pesquisa Agropecuária Brasileira 41(6): 937-942

Nutter Jr F W, Kuhn C W \& All J N (1989). Models to estimate yield losses in bell pepper caused by tobacco etch virus epidemics. Phytopathology 79: 1213

Padgett B G, Nutter Jr F W \& Kuhn C W (1987). Effect of disease resistance on tobacco etch virus epidemics in bell pepper. Phytopathology 77: 643 
Padgett B G, Nutter Jr F W, Kuhn C W \& All C N (1990). Quantification of disease resistance that reduces the rate of tobacco etch virus epidemics in bell pepper. Phytopathology 80: 451-455

Pazarlar S, Gümüş M \& Öztekin G B (2013). The effects of tobacco mosaic virus infection on growth and physiological parameters in some pepper varieties (Capsicum annuum L.). Notulae Botanicae Horti Agrobotanici 41(2): 427-433

Ramkat R C, Wangai A W, Ouma J P, Rapando P N \& Lelgut D K (2006). Effect of mechanical inoculation of tomato spotted wilt tospovirus disease on disease severity and yield of greenhouse raised tomatoes. Asian Journal of Plant Sciences 5(4): 607-612
Sevik M A \& Arl1-Sokmen M (2012). Estimation of the effect of Tomato spotted wilt virus (TSWV) infection on some yield components of tomato. Phytoparasitica 40: $87-93$

Taiwo M A \& Akinjogunla O J (2006). Cowpea viruses: Quantitative and qualitative effects of single and mixed viral infections. African Journal of Biotechnology 5(19): 1749-1756

TSI (2017). Turkish Statistical Institute Databases Crop Production Statistics https://biruni.tuik. gov.tr/medas/?kn=92\&locale=tr (Date of access: 13.03.2018; 9.20) 